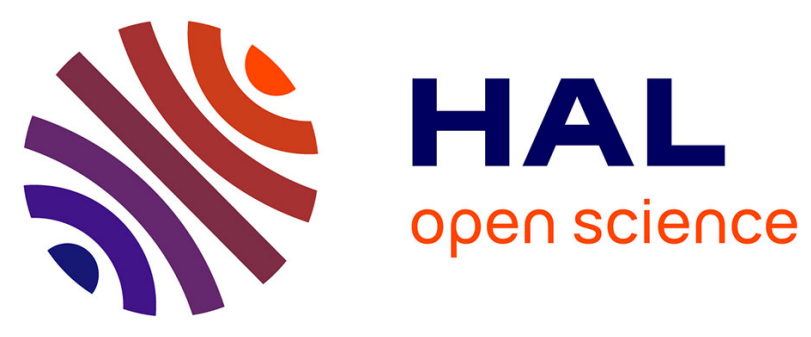

\title{
Study of synergetic effect, catalytic poisoning and regeneration using dielectric barrier discharge and photocatalysis in a continuous reactor: Abatement of pollutants in air mixture system
}

Wala Abou Saoud, Aymen Amine Assadi, Monia Guiza, Abdelkrim Bouzaza, Wael Aboussaoud, Abdelmottaleb Ouederni, Isabelle Soutrel, Dominique Wolbert, Sami Rtimi

\section{- To cite this version:}

Wala Abou Saoud, Aymen Amine Assadi, Monia Guiza, Abdelkrim Bouzaza, Wael Aboussaoud, et al.. Study of synergetic effect, catalytic poisoning and regeneration using dielectric barrier discharge and photocatalysis in a continuous reactor: Abatement of pollutants in air mixture system. Applied Catalysis B: Environmental, 2017, 213, pp.53-61. 10.1016/j.apcatb.2017.05.012 . hal-01542763v2

HAL Id: hal-01542763

https://hal-univ-rennes1.archives-ouvertes.fr/hal-01542763v2

Submitted on 7 Jul 2017

HAL is a multi-disciplinary open access archive for the deposit and dissemination of scientific research documents, whether they are published or not. The documents may come from teaching and research institutions in France or abroad, or from public or private research centers.
L'archive ouverte pluridisciplinaire HAL, est destinée au dépôt et à la diffusion de documents scientifiques de niveau recherche, publiés ou non, émanant des établissements d'enseignement et de recherche français ou étrangers, des laboratoires publics ou privés. 


\title{
Study of synergetic effect, catalytic poisoning and regeneration using dielectric barrier discharge and photocatalysis in a continuous reactor: Abatement of pollutants in air mixture system
}

\author{
Wala ABOU SAOUD ${ }^{1,2}$, Aymen Amine ASSADI ${ }^{1 *}$, Monia GUIZA ${ }^{2}$, Abdelkrim BOUZAZA ${ }^{1}$, Wael \\ ABOUSSAOUD ${ }^{2}$, Abdelmottaleb OUEDERNI ${ }^{2}$, Isabelle SOUTREL ${ }^{1}$, Dominique WOLBERT ${ }^{1}$, \\ Sami RTIMI ${ }^{3 *}$ \\ ${ }^{1}$ Laboratoire Sciences Chimiques de Rennes - équipe Chimie et Ingénierie des Procédés, UMR 6226 \\ CNRS, ENSCR-11, allée de Beaulieu, CS 508307-35708 Rennes, France. \\ ${ }^{2}$ Laboratory process engineering and industrial systems (GPSI), National School of Engineers of Gabes \\ (ENIG), University of Gabes (UG), Omar Ibn Elkhatab Street, Zrig 6029 Gabes, Tunisia. \\ ${ }^{3}$ Ecole Polytechnique Fédérale de Lausanne, EPFL-STI-LTP, Station 12, CH-1015 Lausanne, \\ Switzerland. \\ * Corresponding author. Tel.: +33 2 23238152; fax: +33 223238120. \\ E-mail address: aymen.assadi@ensc-rennes.fr (A. ASSADI), sami.rtimi@epfl.ch (S. RTIMI).
}

\begin{abstract}
In the present work the abatement of butyraldehyde (BUTY), dimethyl disulfide (DMDS) and their mixtures in gas phase was studied in continuous reactor at three different configurations: photocatalysis $\left(\mathrm{TiO}_{2}+\mathrm{UV}\right)$, dielectric barrier discharge (DBD) plasma and their association in the same system (DBD+ $\mathrm{TiO}_{2}+\mathrm{UV}$ ). The effect of some operating parameters such as inlet concentration of pollutant and flowrate on planar reactor performance in term of (i) BUTY removal (ii) selectivity of $\mathrm{CO}$ and $\mathrm{CO}_{2}$, selectivity of byproducts has been also investigated. Moreover, ozone formation has been studied to evaluate the performance of the combined process. A synergetic effect was observed by combining (DBD) plasma and photocatalysis on BUTY removal but has not been present when it was in air mixture with dimethyl disulfide (DMDS) due to the poisoning of the catalyst. Additionally, degradation was observed as a consequence of by-products accumulation on the surface of the catalyst. Moreover, the regeneration/recovery of the initial photocatalytic activity was explored in details. A significant regeneration has been occurred by combining photocatalysis and nonthermal plasma. This trend of nonthermal plasma on catalytic surface can explain the synergetic effect during the pollutant degradation time. Moreover, the catalyst was concomitant with the time required for the hydrophobic to hydrophilic transition on the catalyst surface as followed by contact angle measurement (CA). Redox catalysis was detected by X-ray Photoelectron Spectroscopy (XPS) showing $\mathrm{Ti}^{4+} / \mathrm{Ti}^{3+}$ switching during the degradation, poisoning and regeneration times.
\end{abstract}

Keywords: Sulfur compounds, Dielectric Barrier Discharge, Photocatalysis, Synergetic effect, Catalyst poisoning, Catalytic regeneration. 


\section{Introduction}

The emission of volatile organic compounds (VOCs) is a major source of air pollutants, coming largely from industrial sectors especially by the petrochemical, and therefore, poses serious damages to environment and public health [1-3]. Sulfur containing volatile organic compounds (SVOCs) constitutes one of the important families of atmospheric pollutants such as methyl mercaptan $\left(\mathrm{CH}_{3} \mathrm{SH}\right)$,dimethyl sulfide $\left(\mathrm{CH}_{3} \mathrm{SCH}_{3}\right)$ and dimethyl disulfide $\left(\mathrm{CH}_{3} \mathrm{SSCH}_{3}\right)$ [4,5].These mentioned compounds are coming either from natural processes like anaerobic biological activities or from anthropogenic emissions sectors such as pulping processes and chemical industries. First and foremost, these sulfur compounds are known by their high toxic and corrosive effect $[4,6,7]$. Besides, they are causing significant environmental problems. In fact, their oxidation in the atmosphere will lead to the production of sulfur dioxide $\left(\mathrm{SO}_{2}\right)$, which be consequently converted into sulfuric acid and returns to the earth when it rains [4]. Therefore, the abatement of those odorous emissions in the atmosphere is an important issue that needs an efficient and least-cost process. Adsorption [8], thermal oxidation [9], biological treatment [10], ozonation [11], and catalysis/photocatalysis [12] have been proposed by researchers as conventional VOCs treatment methods.

Photocatalysis is a promising technology for air purification because of its ability to break down a wide range of pollutants to non-toxic end-products such as $\mathrm{CO}_{2}$ and $\mathrm{H}_{2} \mathrm{O}$ under ambient conditions $[13,14]$. The latter processes based on photoreactions which take place at the surface of a semiconductor usually titanium dioxide $\left(\mathrm{TiO}_{2}\right)$ under ultraviolet (UV) irradiation [15-18]. Some significant results have been achieved in the photocatalytic oxidation of many organic compounds like VOCs and SVOCs which includes dimethyl sulfide [19], ethyl mercaptan [20], hydrogen sulfide [21], BTEX (Benzene, Toluene, Ethylbenzene and Xylenes) removal [22] and isovaleraldehyde [23]. Moreover, several researchers have investigated non-thermal plasma (NTP) as one of the technologies which can be used to treat polluted air [24-26]. This techniques characterized by its high efficiency in the formation of reactive chemical species like hydroxyl radicals, atomic oxygen and ozone, which may react and degrade organic molecules at room temperature under atmospheric pressure [26-28]. In fact, dielectric barrier discharge (DBD), one of the NTP techniques, has been employed successfully for the abatement of various aromatic VOCs: toluene [29] and benzene [30], trimethylamine [31], hydrogen sulfide [32], and sulfur dioxide [33]. Several studies have reported on the combined process between non-thermal plasma (NTP) and photocatalysis leading to improve the efficiency of VOCs degradation [34-39] over a synergistic effect [29-32].

The aim of the present work is to explore the removal efficiency of butyraldehyde (from now as BUTY), dimethyl disulfide (from now as DMDS) and their mixtures in planar reactor, using dielectric barrier discharge (DBD) plasma (from now as DBD-plasma) and photocatalysis processes separately and their combinations in the same reactor. The influence of inlet concentration and flowrate on the pollutants removal, nature of the by-products and ozone formation inside the process are studied in details. Moreover, an interesting challenge of this work is to study the presence of synergetic effect between DBD-plasma and photocatalysis during the oxidation of mixture of VOCs at pilot scale. A special attention is paid to $\mathrm{TiO}_{2}$ poisoning and its regeneration with different process oxidation (plasma, 
photocatalysis and combined system). The evidence for redox catalysis responsible for the photocatalytic activity was also investigated.

\section{Materials and methods}

\subsection{Reactor design and setup details}

The reactor consists of a rectangular glass chamber (length $L=1000 \mathrm{~mm}$, width I $=135 \mathrm{~mm}$ and height $\mathrm{H}=135 \mathrm{~mm}$ ). Two glass plates are installed parallel to the length of the reactor and permit to maintain the catalyst, the two electrodes $(1 \mathrm{~mm}$ thick and $800 \mathrm{~mm}$ in length) and high voltage grids (stainless steel, $2 \mathrm{~mm}$ thick). To generate the plasma, high voltage is applied to the reactor. The applied voltage is delivered by a generator (BFi OPTILAS) as a sinusoidal waveform up to $10 \mathrm{~V}$ and then amplified by an amplifier (TREK 30/40) to achieve $30 \mathrm{kV}$. This amplifier is connected to the electrodes. A coil of capacitors with a total capacity of $2.5 \mathrm{nF}\left(\mathrm{C}_{\mathrm{m}}\right)$ was positioned between the copper electrode and the ground connection in order to collect the charges in the reactor. The distance between the two plates could be adjusted to modify the space/air gap. The voltage applied $\left(U_{\text {app }}\right)$ and the high voltage capacity $\left(U_{m}\right)$ are measured by high-voltage probes recorded with a digital oscilloscope (Lecroy wave surfer $24 \mathrm{Xs}, 200 \mathrm{MHz}$ ). The reactor can be used also as a photocatalytic reactor and as a plasma DBDphotocatalytic reactor. Eight lamps (Philips under reference PL-S 9W/10/4P) are placed equidistant from each other in air gap of the reactor in order to ensure a good radiation distribution (Figure 1). The photocatalyst is maintained between the stainless steel grid electrode and the dielectric barrier in the plasma active area. The UV lamps arranged in the reactor, permit the activation of the photocatalyst. Two openings with septum downstream and upstream of the reactor allow outlet and inlet gas to be sampled with a $500 \mu \mathrm{L}$ syringe.

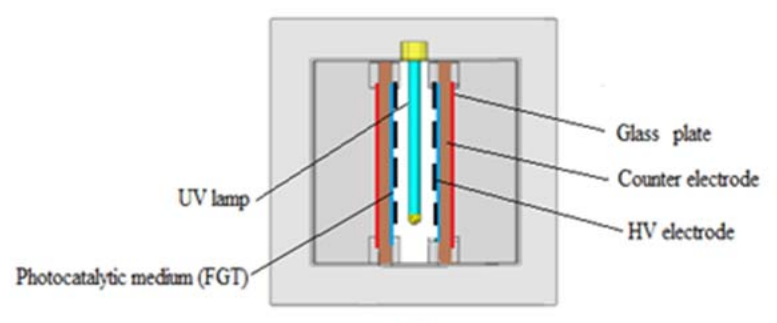

(a)

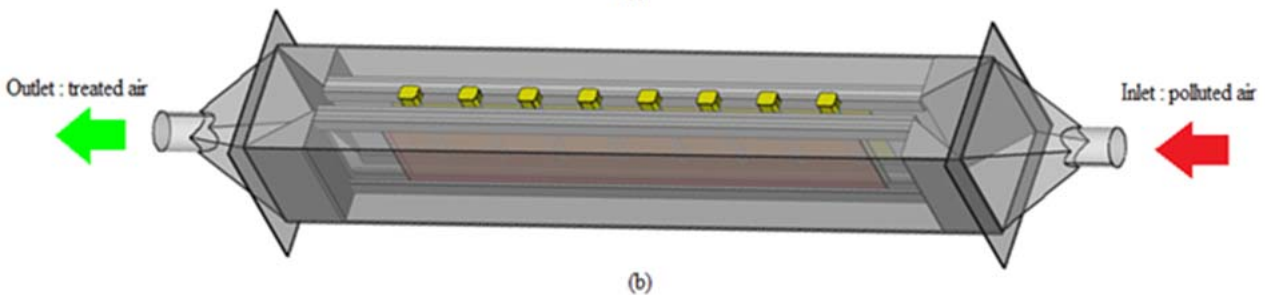

Figure 1. Schematic illustration of the used set-up: (a) sectional drawing and (b) planar reactor.

\subsection{Catalysts}

The supported material is further named Glass Fiber Tissue (GFT) containing $13 \mathrm{~g} / \mathrm{m}^{2}$ of colloidal silica, a $13 \mathrm{~g} / \mathrm{m}^{2}$ of titanium dioxide nanoparticles and inorganic fibers. The coating process consists in an impregnation of glass fibers by $\mathrm{SiO}_{2}$ and $\mathrm{TiO}_{2}$ nanoparticles suspension in pure water using an 
industrial size-press (PC500 Millennium). The specific area of $\mathrm{TiO}_{2}$ nanoparticles is $300 \mathrm{~m}^{2} / \mathrm{g}$. The coating process consists in impregnating fibers using industrial size press. The press is employed to impregnate fibers with the suspension; then, they are dried (Figure 2). Material preparation has been performed by Ahlstrom Research and Services.

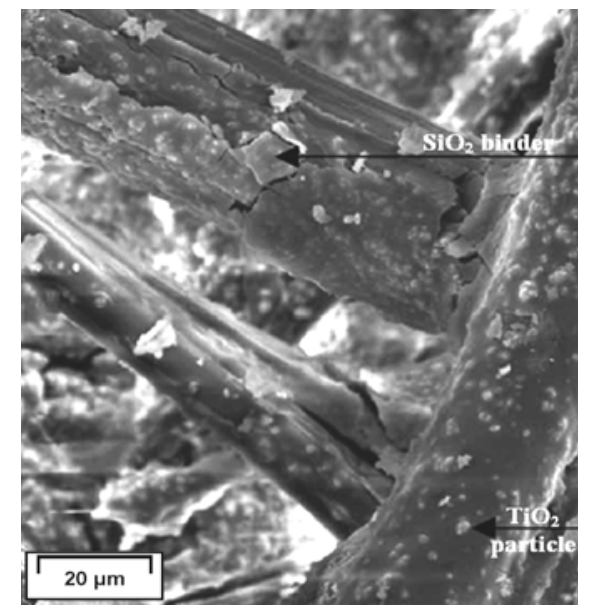

Figure 2. SEM imaging of $\mathrm{TiO}_{2}$ deposited on GFT [38].

\subsection{Polluted flow generation}

The generated flow rate is controlled by a mass flow meter (Bronkhorst In-Flow) with a maximum flow rate reached about $10 \mathrm{~m}^{3} \mathrm{~h}^{-1}$. In order to keep the value of relative humidity $(\mathrm{RH})$ of the gas constant a variable part of the air flow is derived through a packed column where water flows in counter current and the $\mathrm{RH}$ value was about $50 \%$ (Figure 3 ).

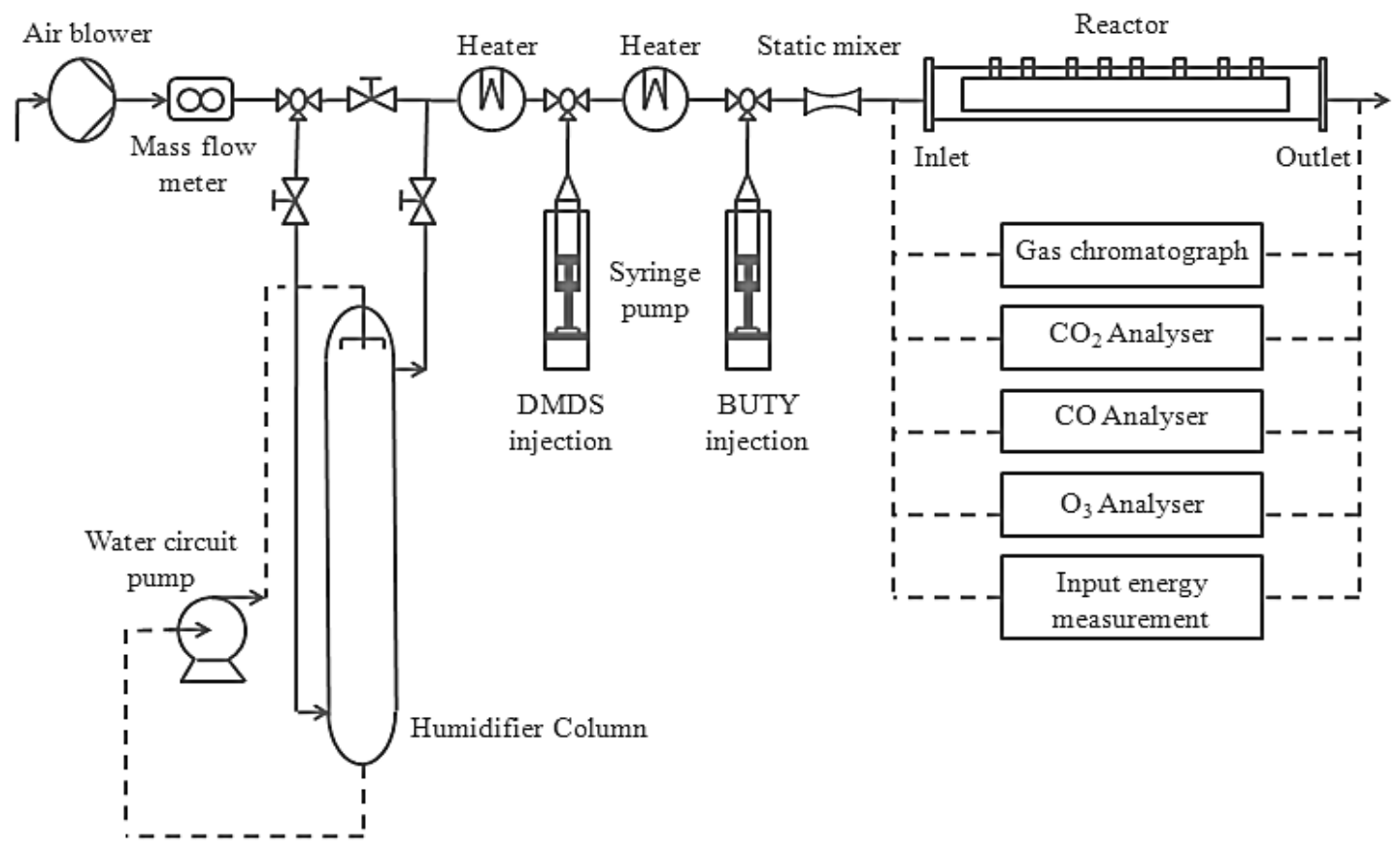

Figure 3. Experimental setup. 
The pollutants, BUTY and DMDS, are injected continuously in liquid state by means of a syringe/syringe driver system (Kd Scientific Model 100) through a septum into the gas stream. A heating tape was wrapped around the pipe at the injection zone in order to ensure a good evaporation of each pollutant. A static mixer allows the homogenization of the upstream effluent (Figure 3). We note that all experiments were carried out at room temperature and atmospheric pressure. A TESTO sensor is used to measure the temperature and relative humidity.

\subsection{Analysis system}

Analysis of BUTY was performed using a gas phase chromatograph (Fisons GC9000) equipped with a flame ionization detector (FID). Nitrogen was used as the carrier gas and constitutes the mobile phase. All injections were performed manually with a syringe of $500 \mu \mathrm{L}$ and repeated at least three times and DMDS was analyzed by another gas phase chromatograph (THT MEDOR ${ }^{\circledR}$ ), also all injections were performed manually with a bag of $5 \mathrm{~L}$, sampling was done in cycles; each cycle lasts $30 \mathrm{~min}$. More details about the analysis system of the sulfur compounds had been described in detail in our previous work [40].

\section{5. $\mathrm{CO}_{\mathrm{x}}, \mathrm{SO}_{2}$ and $\mathrm{O}_{3}$ analysis}

The $\mathrm{CO}_{2}$ was analyzed by a Fourier Transform Infrared (FTIR) spectrophotometer brand Environment $\mathrm{SA}$. The $\mathrm{CO}$ concentration was measured by $\mathrm{NO} / \mathrm{CO}$ ZRE gas analyzer and $\mathrm{SO}_{2}$ concentration was measured by MEDOR gas analyzer.

A standard iodometric titration method was used to estimate the downstream ozone formation. Thus, at the reactor exit, a constant air flow of $285 \mathrm{~L} \mathrm{~h}^{-1}$ is bubbled in a potassium iodide $(\mathrm{KI})$ solution at $10^{-2} \mathrm{M}$. A yellowish solution is obtained when $\mathrm{I}^{-}$oxidizes into $\mathrm{I}_{2}[41]$.

\subsection{Surface wettability, oxidative states as determined by XPS and OH-radical production as determined by fluorescence}

Sessile drop method on a Data Physics OCA 35 unit was used to evaluate the wettability of the catalyst surface by determining the water droplet contact angle (CA).

The X-ray photoelectron spectroscopy (XPS) of the photocatalyst was determined using an AXIS NOVA photoelectron spectrometer (Kratos Analytical, Manchester, UK) provided for with monochromatic AIKa ( $\mathrm{hn}=1486.6 \mathrm{eV}$ ) anode. The carbon $\mathrm{C} 1 \mathrm{~s}$ line with position at $284.6 \mathrm{eV}$ was used as a reference to correct the charging effects. The surface atomic concentration was determined by XPS from the peak areas, using recognized sensitivity factors. The surface percentages composition was determined within the topmost atomic layers. The XPS spectra were deconvoluted by the mean of a Casa XPS updated version 2.3.18.

The quantification of the ${ }^{\circ} \mathrm{OH}$ radical was carried out based on the method proposed by Hashimoto et al., [42]. For this, an Across Chemicals $99 \%$ terephthalic acid as well as $\mathrm{NaOH} 98 \%$ from Sigma Aldrich were used. The samples were immersed in a $0.4 \mathrm{mmol} \mathrm{L}^{-1}$ solution of terephthalic acid dissolved in a 4 mmol $\mathrm{L}^{-1} \mathrm{NaOH}$ solution. After UV-irradiation, the solution was transferred in a quartz cell. The fluorescence of the 2-hydroxyterephthalic-acid was quantitatively monitored on a Perkin Elmer LS-50B 
spectrometer. The spectra were recorded at scan rate of $100 \mathrm{~nm} / \mathrm{min}$ in wavelength range between 400-500 $\mathrm{nm}$ after excitation at $315 \mathrm{~nm}$.

\section{Results and discussion}

The evaluation of the process performance was done by estimating: the removal efficiency (RE), the carbon monoxide selectivity (SCO), the carbon dioxide selectivity $\left(\mathrm{SCO}_{2}\right)$ and the specific energy (SE). These were determined according to the equations defined as follows (eq.1-5):

- Removal efficiency (RE) of each pollutant:

$$
\mathrm{RE}(\%)=\frac{\mathrm{c}^{\text {in }}-\mathrm{c}^{\text {out }}}{\mathrm{c}^{\ln }} \times 100
$$

Where $\mathrm{C}^{\text {in }}$ and $\mathrm{C}^{\text {out }}$ are the inlet and the outlet concentrations of pollutants $\left(\mathrm{mg} \mathrm{m}^{-3}\right)$ respectively.

- $\quad$ Selectivity of CO:

$$
\mathrm{sco}(\%)=\frac{[\mathrm{Co}]^{\text {out }}-[\mathrm{Co}]^{\mathrm{nn}}}{4 \times \operatorname{RE}(\%) \times[\mathrm{BUTY}]_{\mathrm{bu}}} 10^{4}
$$

- $\quad$ Selectivity of $\mathrm{CO}_{2}$ :

$$
\mathrm{sCO}_{2}(\%)=\frac{\left[\mathrm{CO}_{2}\right]^{\text {out }}-\left[\mathrm{CO}_{2}\right]^{\mathrm{hn}}}{4 \times \mathrm{RE}(\%) \times[\mathrm{BUTY}]_{\mathrm{III}}} 10^{4}
$$

- $\quad$ Specific energy (SE):

$$
\begin{gathered}
\mathbf{r}(\mathrm{w})=\mathbf{H}(\hat{\mathrm{N}} \times \text { Hrequency }(\mathrm{Hz}) \\
\mathrm{SE}\left(\frac{\mathrm{I}}{\mathrm{L}}\right)=\mathbf{P} \times \frac{\mathbf{Q}}{1000}
\end{gathered}
$$

where $Q\left(\mathrm{~m}^{3} \mathrm{~s}^{-1}\right)$ is the flow rate and $\mathrm{P}(\mathrm{W})$ is input power adjusted by changing the applied voltage $\left(\mathrm{V}_{\mathrm{a}}\right)$. The present work aimed at the removal of mixture of VOCs of different nature. Therefore, in order to understand the oxidation behavior of VOCs in a mixture, initial experiments were carried out on each compound alone.

The pollutants analysis was started only once the air flow in the reactor reaches an equilibrium. In other words, a certain time was required after the pollutant is injected in the air flow crossing the reactor, so that its concentration stabilizes. Once the outlet concentration is stabilized and the catalyst is loaded, the oxidation starts and thus samples can be taken for analysis.

\subsection{Oxidation of BUTY}

\subsubsection{Effects of inlet concentration and flow rate with photocatalytic process}

Inlet concentration and flowrate were varied in order to understand their influences on the performance of the photocatalytic reactor. The removal efficiency (RE) of BUTY at different inlet concentrations and 
gas flow rates is shown in Figure 4. The inlet concentration of BUTY was varied from 25 to $150 \mathrm{mg} \mathrm{m}^{-3}$ in the flow rate range of 4 to $8 \mathrm{~m}^{3} \mathrm{~h}^{-1}$. It is readily seen in Figure 4 that the removal efficiency of BUTY declines with increasing the flow rate, this is due to decreased contact time between the compound and the catalytic active sites. However, it can be noted also that with increasing the inlet concentration, the degradation rate of BUTY decreased; this behavior is well known and could be explained by the less effective availability of the active sites on catalyst surface $[16,23,39]$.

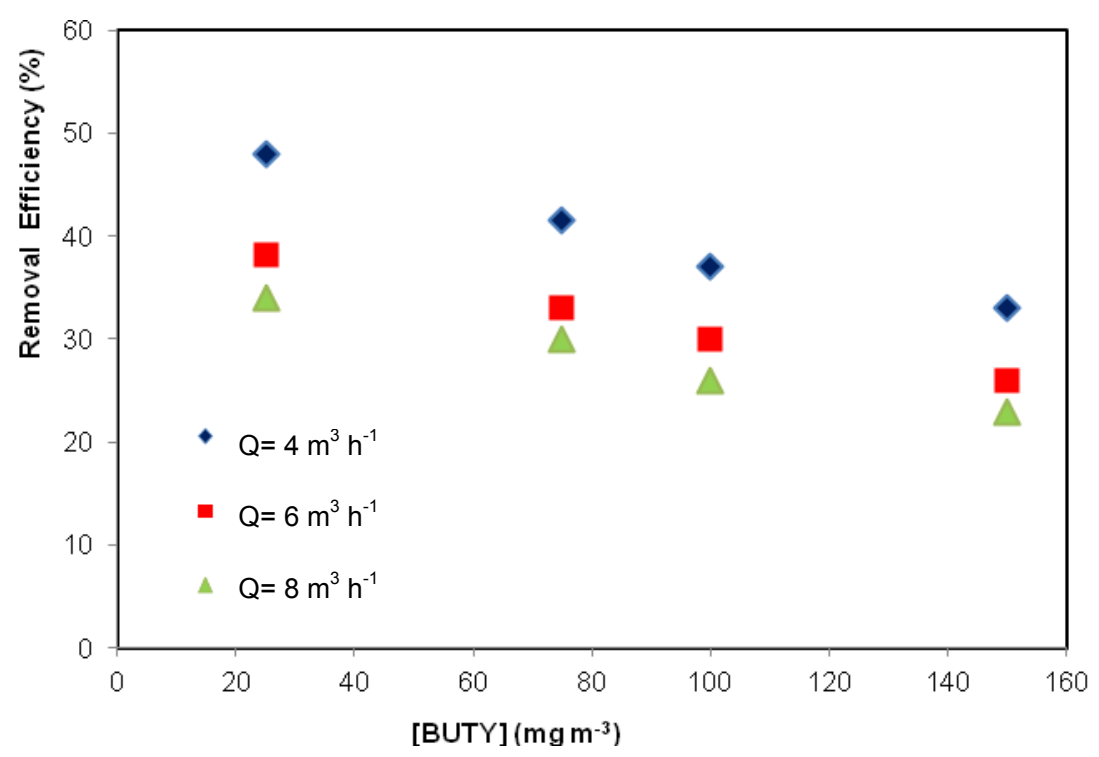

Figure 4. Removal efficiency (RE) of BUTY with inlet concentration at different flow rates (Process tested: Photocatalysis, UV intensity $=20 \mathrm{~W} \mathrm{~m}^{-2}, \mathrm{RH}=50 \%$ ).

\subsubsection{Effect of specific energy (SE) with plasma and combined system}

It is well known that the energy of discharge injected in the reactor is an important parameter. Thus in order to understand its effect, two studies of BUTY removal by DBD plasma reactor taken alone and combined with photocatalysis were carried out. It is interesting to note that, in our previous investigations [17, 44], results show that the UV light generated by surface discharge plasma in a continuous reactor for isovaleraldehyde removal did not activate $\mathrm{TiO}_{2}$ and its contribution to pollutants elimination can be neglected. Moreover, it was shown by Thevenet et al. [38] that the UV produced by the plasma is not sufficient to activate photocatalyst during $\mathrm{C}_{2} \mathrm{H}_{2}$ degradation. Thus, the introduction of external UV light to the plasma is indispensable for maintain the photocatalytic activity of $\mathrm{TiO}_{2}$.

The BUTY inlet concentration was around $45 \mathrm{ppm}$ under a flow rate of $4 \mathrm{~m}^{3} \mathrm{~h}^{-1}$ in the SE range of 2-10 $\mathrm{J} \mathrm{L}^{-1}$ as showed in Figure 5. When only DBD plasma was used at SE equal to $9.945 \mathrm{~J} \mathrm{~L}^{-1}$, the BUTY removal was $28 \%$. However, by coupling photocatalysis and DBD plasma, the BUTY removal reached $53 \%$ with respect to the removal efficiency of $18 \%$ when photocatalysis was applied alone. Therefore, a synergetic effect is happening on the catalyst surface when applying both processes e.g. plasma and photocatalysis. This trend was the same for all the values of injected specific energy in the reactor. This is due to the role of neutrals (including molecules, radicals, metastable species and atoms), ions, electrons, photons and electric fields, on enhancing of plasma-catalyst surface interactions in terms of 
surface chemical reactions and enhancing of mass transfer [43]. Similar observations have been mentioned in the literature for various VOCs. [36, 38, 43-45].

The synergetic effect seen on the photocatalytic surface can be attributed to: i) the non-thermal plasma involving various processes since the plasma produces many species such as high-energy electrons, excited molecules or radicals $\left(\mathrm{O}^{\circ}, \mathrm{N}, \mathrm{HO}, \mathrm{O}_{2}{ }^{\circ}, \mathrm{O}_{3}, \mathrm{NO}_{2}, \mathrm{NO}_{x}\right.$, etc.). These species can interact with BUTY molecules leading to its degradation and ii) plasma promoting the desorption of byproducts attached at the $\mathrm{TiO}_{2}$ surface leading to its mineralization iii) Plasma can induce activation of the $\mathrm{TiO}_{2}$ by creating hole/ electron pairs through ion bombardment $[50,25,43]$.

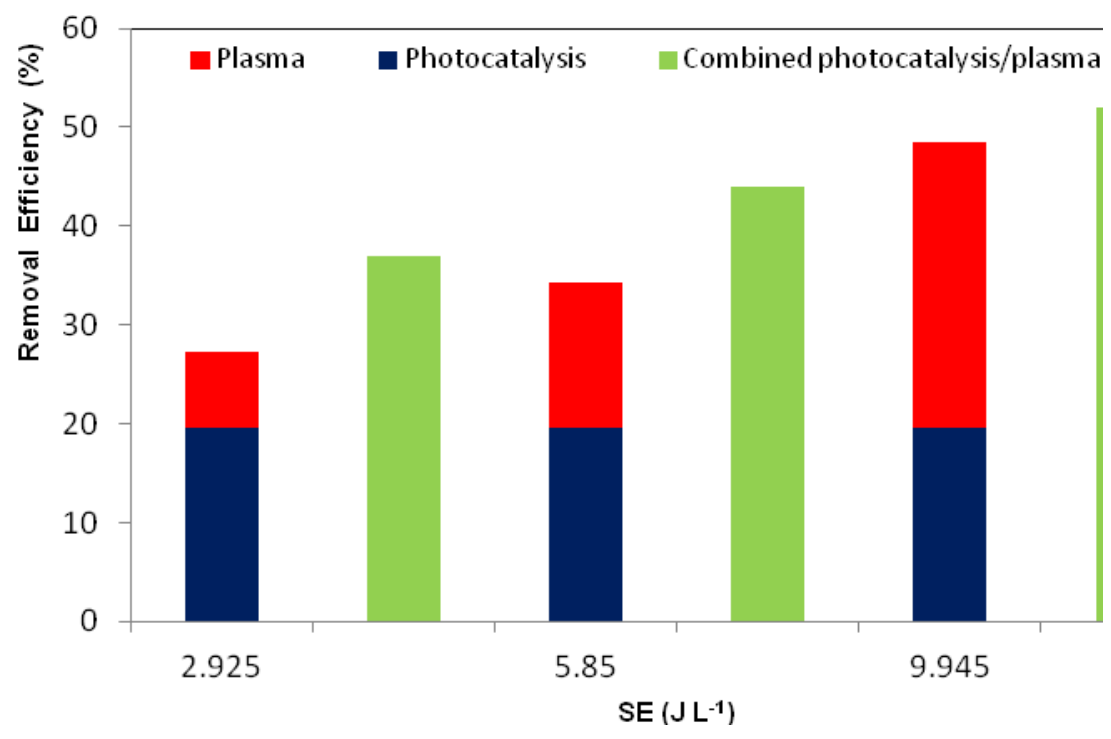

Figure 5. BUTY removal efficiency at different SE when applying DBD plasma, photocatalysis and their combination: Evidence for synergetic effect $\left(\mathrm{Q}=4 \mathrm{~m}^{3} \mathrm{~h}^{-1}\right.$, [BUTY] $\left.=45 \mathrm{ppm}, \mathrm{RH}=50 \%\right)$.

\subsection{3. $\mathrm{CO}_{x}$ selectivites and ozone formation}

Figure 6 shows the variation of $\mathrm{CO}_{\mathrm{x}}$ selectivies (\%) and the amount of ozone (ppm) produced when applying DBD plasma, photocatalysis and their combination. The production of $\mathrm{CO}$ is seen to below and its selectivity did not exceed $15 \%$. The $\mathrm{CO}_{2}$ selectivity when applying the three processes is also presented in Figure 6. It is readily seen that photocatalysis is the most selective to $\mathrm{CO}_{2}$ among the three processes studied and its selectivity achieved $60 \%$ whereas $\mathrm{SCO}_{2}$ with $\mathrm{DBD}$ plasma alone and coupled processes is $30 \%$ and $45 \%$ respectively. Additionally, it is necessary to note that combining both processes $\left(\mathrm{DBD}+\mathrm{TiO}_{2}+\mathrm{UV}\right)$ ensures a higher BUTY conversion rate and offers great possibility to reduce $\mathrm{O}_{3}$ formation at the outlet of the reactor. However, at SE equal to $9.945 \mathrm{~J} \mathrm{~L}^{-1}$, the ozone outlet concentration is $22.45 \mathrm{ppm}$ and decreases to $15 \mathrm{ppm}$ for combined processes.

This behavior suggests that UV lamp can play a role of ozone decomposition as described in eq. 6 and 7 below $[46,47]$ :

$$
\begin{gathered}
O_{3}+6^{-} \rightarrow 0^{-}+O_{2} \\
O_{3}+h v(254<\lambda<310 \mathrm{~nm}) \rightarrow 0^{+}+0_{2}
\end{gathered}
$$




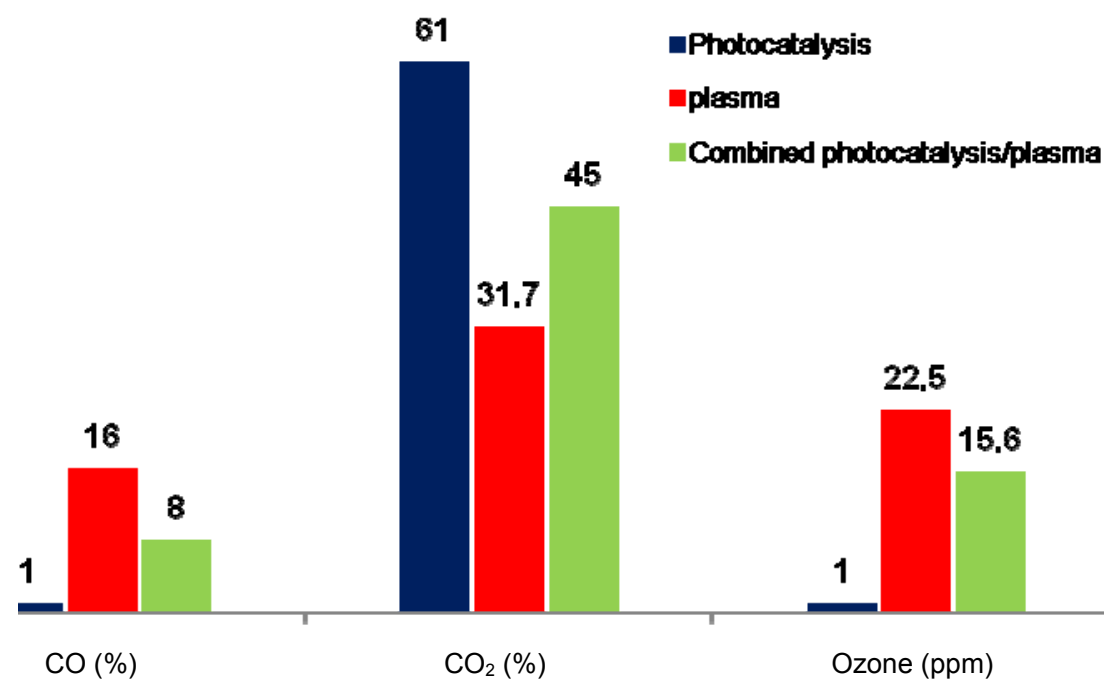

Figure 6. Variation of $\mathrm{CO}_{x}$ selectivity $(\%)$ and the amount of ozone $(\mathrm{ppm})$ when applying the three processes $(\mathrm{Q}=4$ $\left.\mathrm{m}^{3} \mathrm{~h}^{-1},[\mathrm{BUTY}]=45 \mathrm{ppm}, \mathrm{SE}=9.945 \mathrm{~J} \mathrm{~L}^{-1}, \mathrm{RH}=50 \%\right)$.

\subsection{Oxidation of DMDS}

The performance of the reactor during the oxidation of DMDS was tested and the results, using the same planar reactor, are represented in Figure 7. The experiments were carried out at an inlet DMDS concentration of $45 \mathrm{ppm}$ under a flow rate of $4 \mathrm{~m}^{3} \mathrm{~h}^{-1}$ in the SE range of 2 to $10 \mathrm{~J} \mathrm{~L}^{-1}$. Figure 7 shows the variation of the DMDS removal with specific energy for the photocatalysis $\left(\mathrm{TiO}_{2}+\mathrm{UV}\right)$ alone, plasma DBD alone, and for combining both processes. By coupling processes, DMDS is straightforwardly removed as seen in Figure 7. At $\mathrm{SE}=9.945 \mathrm{~J} \mathrm{~L}^{-1}$, the values of $\mathrm{RE}$ are $28 \%, 47 \%$ and $70 \%$ when applying photocatalysis, DBD-plasma and the coupling respectively. Whereas the synergetic effect is not observed with DMDS. Clearly, this behavior is attributed to the catalyst poisoning as a consequence of degradation by-products accumulating on the catalyst surface, beginning with photocatalysis, plasma and then coupled processes at low SE values. 


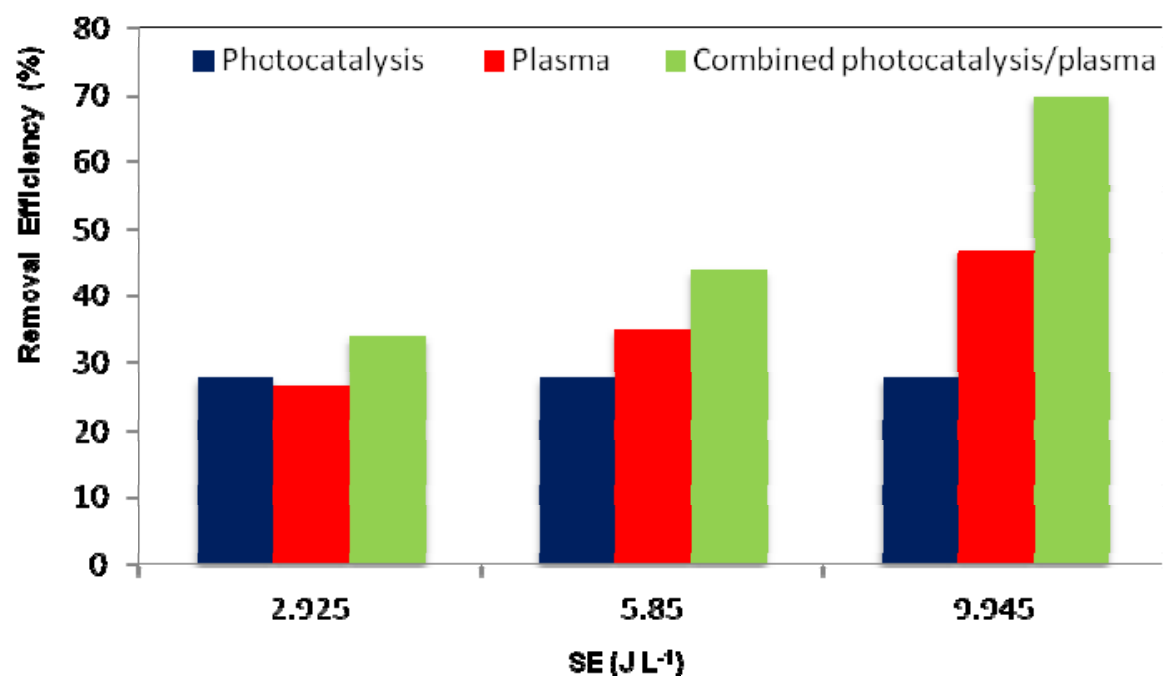

Figure 7. Variation of DMDS removal efficiency with SE when applying the three processes $\left(\mathrm{Q}=4 \mathrm{~m}^{3} \mathrm{~h}^{-1},[D M D S]=\right.$ 45 ppm, RH = 50\%).

\subsection{Oxidation of the mixture BUTY and DMDS}

A mixture of BUTY and DMDS was injected in equal amounts to the incoming air. The experiments were carried out at an inlet concentration of VOCs mixture of $45 \mathrm{ppm}$ (each pollutant concentration is equal to $22.5 \mathrm{ppm}$ ) under a flow rate of $4 \mathrm{~m}^{3} \mathrm{~h}^{-1}$ in the SE range of 3-6 $\mathrm{J} \mathrm{L}^{-1}$. The results for DMDS removal with specific energy using photocatalysis $\left(\mathrm{TiO}_{2}+\mathrm{UV}\right)$ alone, DBD-plasma, and for the coupling of both processes are shown in Figure 8 . When applying photocatalysis, only $5 \%$ of the DMDS was removed. When DBD-plasma was used at $S E=6 \mathrm{~J} \mathrm{~L}^{-1}$, the DMDS removal reached to $10 \%$. By coupling photocatalysis and DBD-plasma, the DMDS removal increased to $15 \%$. In fact, DMDS removal was similar to the sum of removal efficiencies of each process taken separately. Therefore, a synergetic effect was not obviously observed.

Figure 8 shows also BUTY behavior when it is oxidized by photocatalysis, DBD-plasma and by coupling both processes as a function of the injected energy. We noted that BUTY abatement is significantly better than DMDS. At SE equal to $6 \mathrm{~J} \mathrm{~L}^{-1}$, it can be also noted that by photocatalysis alone, the removal efficiency of BUTY was around 19\%. When DBD-plasma alone was used, the BUTY removal reaches $45 \%$. By coupling photocatalysis and DBD-plasma, the BUTY removal increased to $55 \%$. The synergetic effect is not observed with BUTY even if its degradation is higher compared to DMDS. 


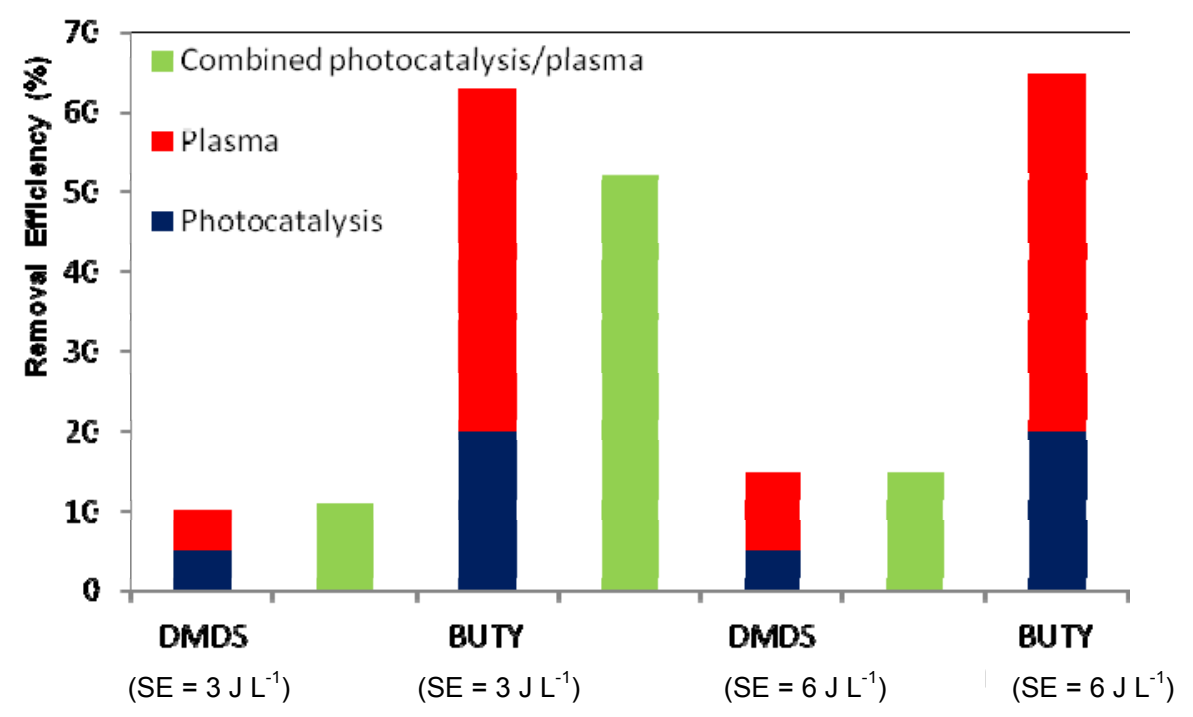

Figure 8. Variation of the removal efficiency of DMDS and BUTY in mixture (50\%-50\%) with SE using the three processes $\left(\mathrm{Q}=4 \mathrm{~m}^{3} \mathrm{~h}^{-1}\right.$, [Mixture] $\left.=45 \mathrm{ppm}, \mathrm{RH}=50 \%\right)$.

\subsection{Photocatalyst poisoning and regeneration: Cyclic photocatalytic oxidation}

To your understanding, the lack of the synergistic effect is due to the catalyst poisoning during the photocatalytic pollutants degradation. Since the photocatalytic oxidation experiments were done in a consecutive way, the photocatalytic oxidation was seen to slow down. This could possibly explain the absence of the synergetic effect during the pollutant degradation. To better understand the influence of poisoning of the catalyst, a series of experiments was carried out. These experiments alternate phases of photocatalysis and of catalyst regeneration. The experiments were performed under dry conditions and continuous flow of $1 \mathrm{~m}^{3} \mathrm{~h}^{-1}$, at an inlet concentration of $45 \mathrm{ppm}$ of BUTY and DMDS mixture (50\%$50 \%$ ). Figure 9. (a) shows the removal efficiency of BUTY versus time during the cyclic studies using the photocatalytic reactor previously described. As can be noted, the removal efficiency of BUTY dropped after $7 \mathrm{~h}$ of irradiation (cycle 1 ), the initial value of RE is about $46 \%$ (Figure 9. (a)). This decrease in the photocatalytic efficiency could be attributed to the adsorption of by-products on the active sites.

Three regeneration procedures were tested to try to reestablish the catalytic capability of the catalyst. The first procedure uses ultraviolet (UV) irradiation without pollutant. Four photocatalytic cycles were done separated with reactivation under UV irradiation as seen in Figure 9. (a). After this first cycle, the reactivation (UV irradiation for $2 \mathrm{~h}$ ) was able to recover $30 \%$ of the efficiency as seen in cycle 2 . At the end of the second cycle, a reactivation of $4 \mathrm{~h} U \mathrm{UV}$-irradiation recovered $21 \%$ as shown in cycle 3 . During cycle 4 , the photocatalytic efficiency is seen to considerably drop down. Therefore, a long-term continuous photocatalytic oxidation may cause poisoning phenomenon $[6,7,21,48]$.

During the second reactivation procedure, DBD-plasma was applied to air stream and then the cyclic photocatalytic oxidation begins again. Figure 9. (b) shows that in these conditions more than $23 \%$ of the 
efficiency was recovered and it can be stated that after DBD-plasma regeneration the removal efficiency of BUTY are less than $23 \%$ compared to initial value of RE.

The third procedure of regeneration is done by combining both regeneration processes (DBD-plasma $\left.+\mathrm{TiO}_{2}+\mathrm{UV}\right)$. By applying this regeneration treatment, the result shows that the initial efficiency of the catalyst was fully recovered. After $4 \mathrm{~h}$ of regeneration, it has been observed that $\mathrm{RE}$ achieved $47 \%$ and then the pollutant removal proceeds as function of time (Figure 9. (c)). This behavior explains the synergetic effect between DBD-plasma and photocatalysis. Thus, it has also been demonstrated that DBD-plasma may effectively regenerate poisoned catalysts. This behavior is similar to what it was reportedby $\mathrm{Kim}$ et al. [49].The latter demonstrated packed-bed plasma regeneration of an $\mathrm{Au} / \mathrm{TiO}_{2}$ catalyst deactivated by the adsorption of VOCs. Moreover, Sivachandrian et al. [50] reported $\mathrm{TiO}_{2}$ surface charged with isopropanol can be generated with plasma in a packed-bed reactor. On the other way, Mok et al. [51] compared thermal and plasma regeneration of a deactivated Ni/alumina catalyst.

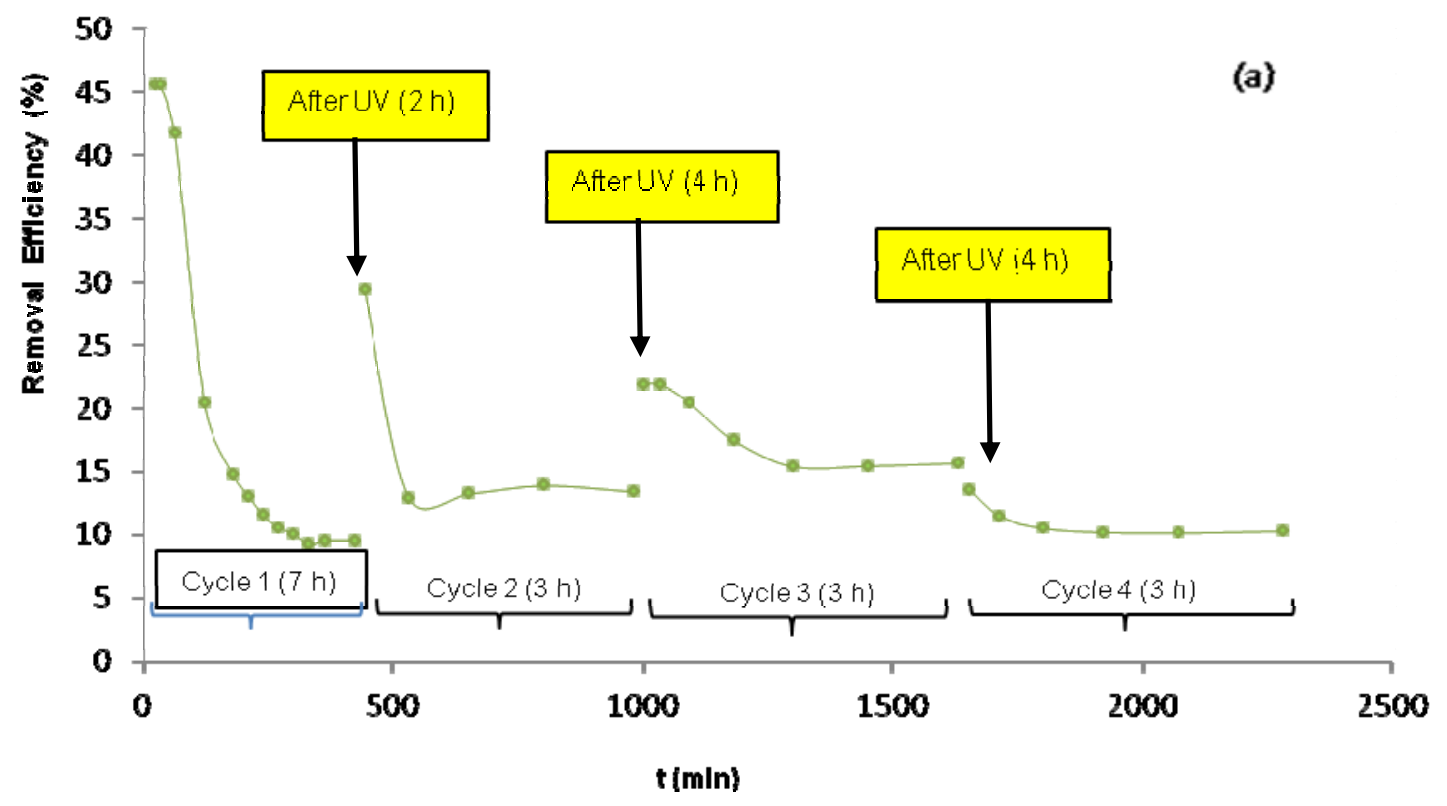



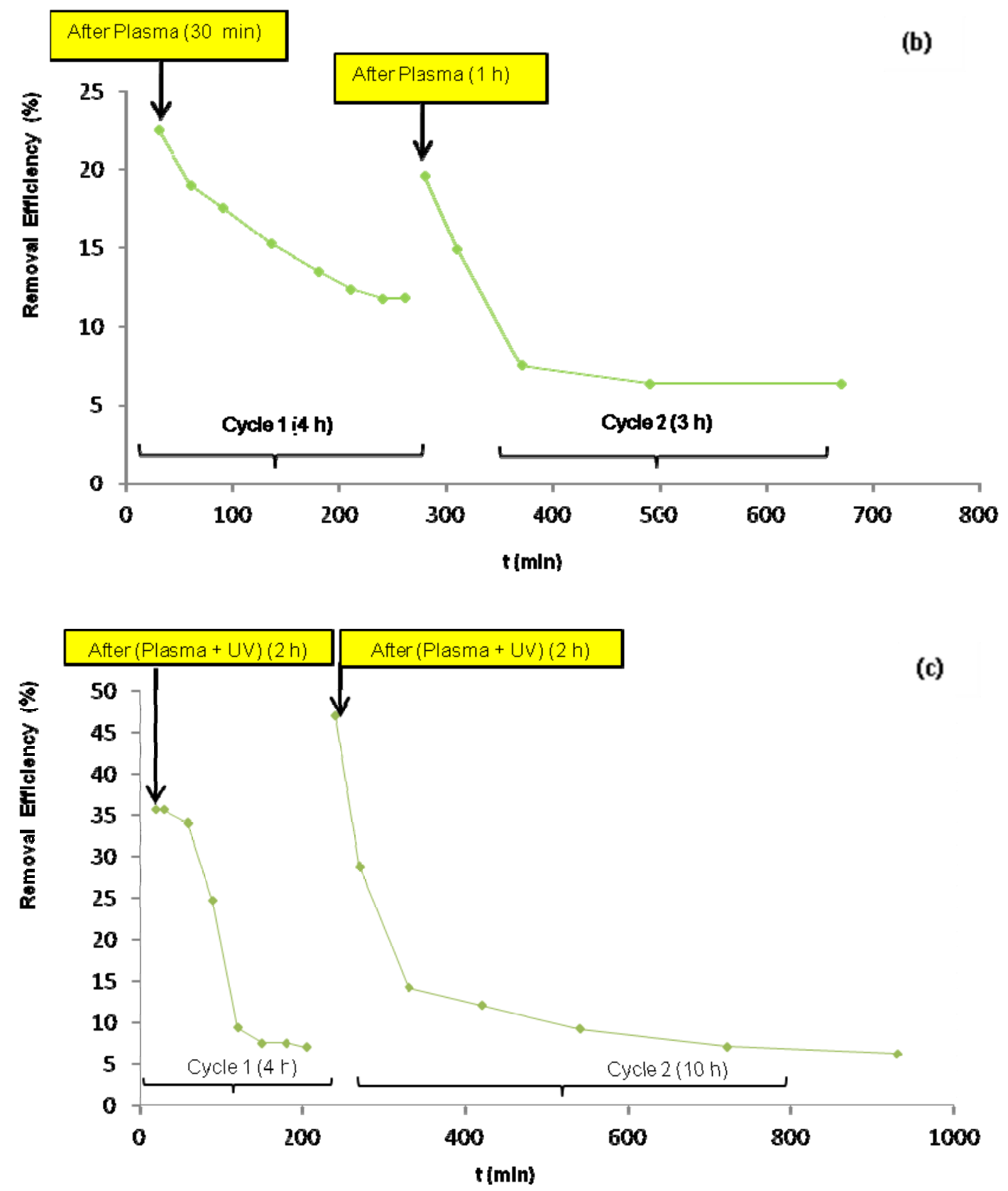

Figure 9. Variation of BUTY removal efficiency as function of time showing catalyst poisoning during the photocatalytic process $\left(\mathrm{Q}=1 \mathrm{~m}^{3} \mathrm{~h}^{-1}\right.$, [Mixture] $\left.=45 \mathrm{ppm}, \mathrm{RH}=5 \%\right)$ with different process of regeneration: (a) process regeneration: photocatalysis, (b) process regeneration: DBD-plasma, (c) process regeneration: DBD-plasma combined with photocatalysis.

\subsection{Surface wettability, oxidative states as determined by XPS and OH-radical production}

Photo-switchable behavior of $\mathrm{TiO}_{2}$ has been reported to happen within the irradiation time. Hydrophobic to hydrophilic transformation aided by water droplets was seen to enhance the photocatalytic pollutant degradation reaction as recently reported [52]. In our case, the contact angle $\theta$ was seen to drop from $96^{\circ}$ until $19^{\circ}$ within the time required for the pollutant degradation. According to Young's theory, when a liquid-vapor interface meets a solid surface an angle of contact is established and can be quantified/estimated using the water droplet contact angle (CA) method. The cosine of the contact 
angle $(\cos \theta)$ of water droplet on a solid surface qualifies of the interfacial energy between the solid and liquid. The three interfacial energies are related to the $\cos \theta$ by the Young's equation as follows (eq. 8):

$$
0=\gamma_{s \theta}-\gamma_{s t}-\gamma_{t \theta} \cos \theta
$$

Where: $\gamma_{s \varepsilon}, \gamma_{s L}$ and $\gamma_{s c}$ are interfacial energy between the solid and the gas, interfacial energy between the solid and the liquid and interfacial energy between the liquid and the gas, respectively.

According to this equation, the rate of the hydrophobic to hydrophilic transformation in our case was assessed to be $0.307 \mathrm{~min}^{-1}$ [53-56]. In other words, this means that the photoactive surface is transformed from hydrophobic to hydrophilic reducing the interfacial energy between the solid surface and the liquid by the mean of the applied light. This aspect was investigated in details and will not be further discussed in the present manuscript [52-53].

Controversy interpretations are seen in the literature discussing if hydrophilic, hydrophobic or mixed hydrophilic-hydrophobic surfaces enhance the pollutant adhesion/contact with the catalytic surface and if this step is a limiting step preceding pollutant oxidation. Recent studies showed that complete Escherichia coli (E.coli) inactivation occurred while $\mathrm{TiO}_{2}$ thin film undergoes the transformation to its hydrophilic state [57].

Redox processes involving $\mathrm{Ti}^{4+} / \mathrm{Ti}^{3+}$ was seen to occur on the catalyst surface during the photocatalytic pollutant degradation. The as-prepared catalyst showed a $\mathrm{Ti}^{4+}$ peak at $458.5 \mathrm{eV}$ coexisting and slightly higher than the $\mathrm{Ti}^{3+}$ peak at $457.8 \mathrm{eV}[52,58]$. But after the catalyst poisoning, the $\mathrm{Ti}^{3+}$ peak amounts to more than $80 \%$ against only $20 \%$ for $\mathrm{Ti}^{4+}$. Surface atomic percentage determined by XPS showed that the poisoned catalytic surface accumulates S2p reaching $22.89 \%$ of the total surface species. This S2p was seen to decrease significantly up to $4 \%$ during the plasma surface regeneration as seen in Table 1 .

Table 1. Surface percentage atomic concentration on the catalyst surface at time zero, after the catalyst poisoning and after the plasma treatment: evidence for surface regeneration.

\begin{tabular}{|l|l|l|l|l|l|l|}
\hline \multicolumn{1}{|c|}{ Sample } & C1s & Ti2p & Si2p & O1s & S2p & N1s \\
\hline As prepared surface & 22.08 & 26.97 & 21.55 & 28.51 & 0.81 & 0.06 \\
\hline Poisoned catalyst & 11.31 & 22.45 & 19.03 & 25.27 & 21.89 & 0.05 \\
\hline (Plasma + UV) regenerated catalyst & 24.05 & 25.22 & 20.11 & 27.11 & 4.44 & 0.07 \\
\hline
\end{tabular}

The redox reaction on the $\mathrm{TiO}_{2}$ was also seen to occur concomitant to the increase of hydrophilicity within the pollutant degradation time observed on the catalyst surface as seen in Table $2[53,58]$.

Table 2. Fraction of $\mathrm{OH} /(\mathrm{Ti}-\mathrm{O}+\mathrm{OH})$ on the catalyst surface.

\begin{tabular}{|l|c|}
\hline & $\mathrm{OH} /(\mathrm{Ti}-\mathrm{O}+\mathrm{OH})$ \\
\hline As prepared surface & 0.11 \\
\hline
\end{tabular}




\begin{tabular}{|l|l|}
\hline Poisoned catalyst & 0.28 \\
\hline (Plasma + UV) regenerated catalyst & 0.39 \\
\hline
\end{tabular}

Additionally, under irradiation light with higher energy (hu) than band gaps $\left(E_{g}\right)$, the surface electrons are excited to conductive band, leaving holes in the valence band (i). Ozone $\left(\mathrm{O}_{3}\right)$ formed by plasma is well known as a strong oxidant which can decompose VOCs at ambient temperature by direct way and also was reported to have a positive effect in terms of activity enhancement and regeneration of $\mathrm{TiO}_{2}$ photocatalyst [38]. This effect likely occurred via the decomposition of ozone under ultraviolet (UV) irradiation into very reactive species such as $\mathrm{O}_{2}{ }^{-}$and ${ }^{\circ} \mathrm{OH}$. Thus, this trend explains the high fraction of $\mathrm{OH}$ in table 2. The depletion of the surface lattice $\mathrm{TiO}_{2}$ oxygen on the samples during the air pollutants abatement leads to O-surface vacancies, but these vacancies are compensated by $\mathrm{O}_{2}^{-}$due to the $\mathrm{c}(\mathrm{e}-)$ reacting with $\mathrm{O}_{2}$ (air). One has to keep in mind that $\mathrm{TiO}_{2}$ mediated photocatalysis is based on the fact that the adsorption of $\mathrm{O}_{2}$ does not proceed on perfectly neutral $\mathrm{TiO}_{2}$ surfaces, but on surfaces with excess negative charge on the surface $\mathrm{TiO}_{2} / \mathrm{Ti}-\mathrm{OH}$ groups as reported by XPS in Table 2 as previously reported [58]. The $\mathrm{O}_{2}$ adsorbed by the nonstoichiometric $\mathrm{TiO}_{2}$ surface under light capture and the photo-generated electron/hole pairs. Figure 10 shows the $\mathrm{OH}$-radical quantification on our photocatalyst. The photo-generation of ${ }^{\circ} \mathrm{OH}$ showed an increase up to $3 \mathrm{~h}$ then a stable production with a little decrease of the generated amount. The latter was attributed to the $\mathrm{TiO}_{2}$ active sites saturation and the surface poisoning by the by-products as explained in the XPS section [58-59].

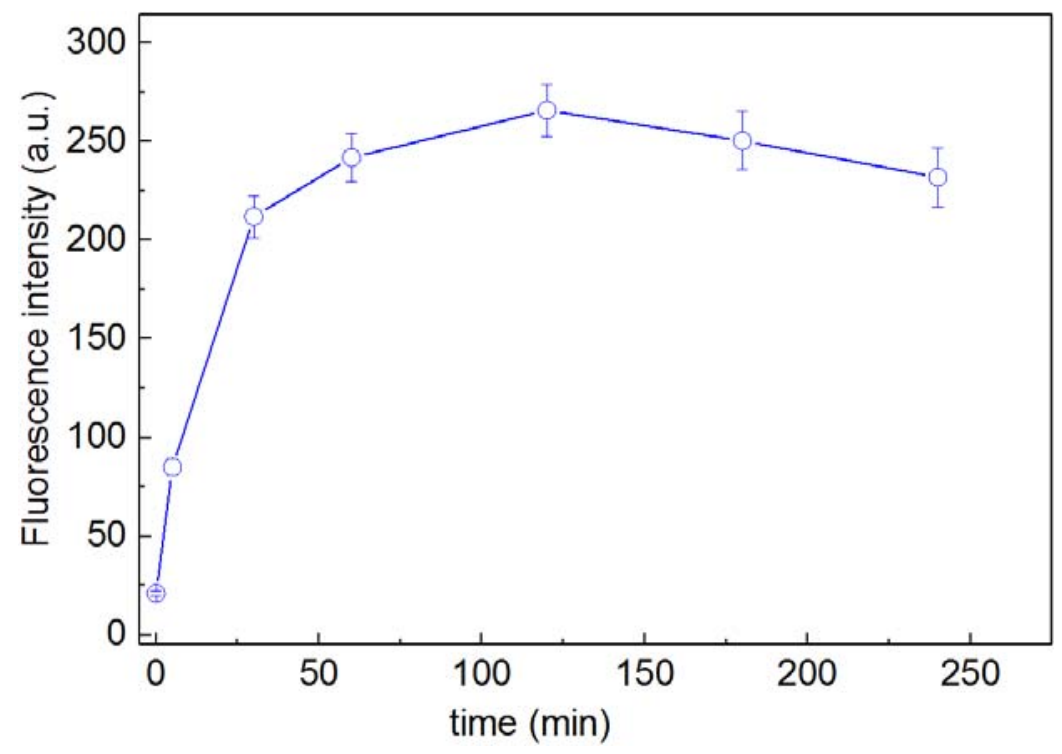

Figure 10. Photo-generation of ${ }^{\circ} \mathrm{OH}$-radical under $\mathrm{UV}$ irradiation on $\mathrm{TiO}_{2}$ deposited on GFT. The measurement were carried out in triplicate, error bars $=5 \%$.

3.6. Suggested mechanism of VOCs removal under $\mathrm{UV} / \mathrm{TiO}_{2} / \mathrm{O}_{3}$ and energy consumption (EC) estimation. 
Under irradiation light with higher energy (hv) than band gaps (Eg), the surface electrons are excited to conductive band, leaving holes in the valence band (i). Ozone $\left(\mathrm{O}_{3}\right)$ formed by plasma is well known as a strong oxidant which can decompose VOCs at ambient temperature by direct way. It was also reported that $\mathrm{O}_{3}$ enhances the regeneration of $\mathrm{TiO}_{2}$ by reacting with the $\mathrm{OH}$-groups and/or the generated $\mathrm{O}_{2}{ }^{\circ-}$ at the photocatalyst interface according to equations 9-10 below. This effect likely occurred through the decomposition of ozone under ultraviolet (UV) irradiation into very reactive species such as $\mathrm{O}_{2}{ }^{\circ}$ and $\mathrm{HO}_{2}{ }^{\circ}$ (ii) leading to effective degradation of VOCs (iii) as shown in the suggested mechanism in scheme 1.
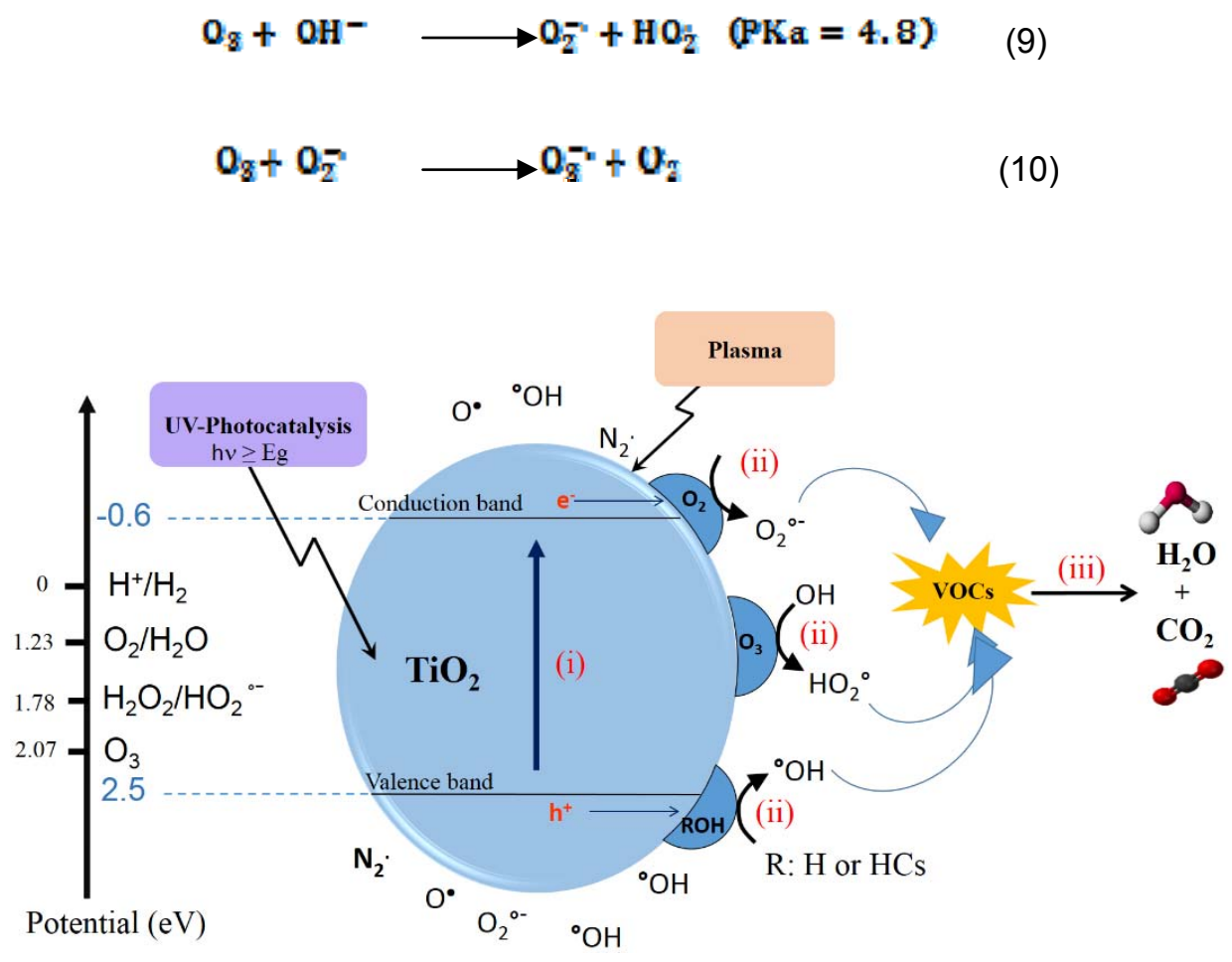

Scheme 1. Suggested mechanism for $\mathrm{VOCs}$ removal under $\mathrm{UV} / \mathrm{TiO}_{2} / \mathrm{O}_{3}$ combined processes.

In order to investigate the different energy consumption of the three processes described in this study, the energy yield $(E Y)$ in units of the mass (in units of mg degraded) of pollutant removed per Wh input $\left(\mathrm{g} . \mathrm{kWh}^{-1}\right)$ is being calculated using the following formula:

- For plasma: $\quad \mathrm{EC}_{\text {piasma }}=\left(\frac{(\mathrm{W} O C]_{\mathrm{in}}-[\mathrm{W} \alpha C]_{\text {ewe }} \mathrm{Y}}{S E}\right)$

- For photocatalysis: $\quad \mathrm{EC}_{\text {photoatalysts }}=\left(\frac{Q\left([P O C]_{\text {in }}-[P O C]_{Q u x}\right)}{N \times P_{\text {inmp }}}\right)$

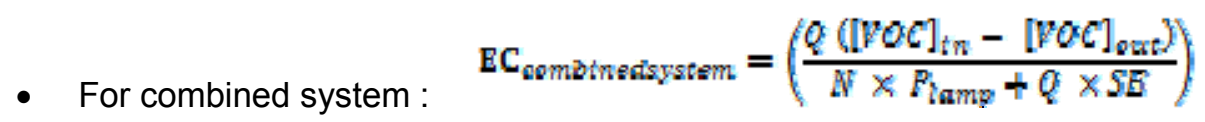


where SE specific energy of plasma, $N$ is number of lamps used, $P_{\text {lamp }}$ is the real power consumption of one UV lamp, $E Y_{\text {plasma }}$ and $E Y_{\text {photocatalysis }} E Y_{\text {combined system }}$ are respectively the energy consumption in plasma, photocatalytic reactor and combined system. The estimated energy consumption (EC) values are in the order of 10 to $204 \mathrm{~g} \cdot \mathrm{kWh}^{-1}$, which is similar to previous studies on mixture of benzene, toluene and ethylene (known as BTEX) [60] and nitrogen oxides $\left(\mathrm{NO}_{\mathrm{x}}\right)$ [61] removal. For the reactor with combined system, EC for Buty removal was higher than that with the others two configurations (plasma and photocatalysis taken alone) as readily seen in Figure 11. This behavior can be due to the in-situ interactions between plasma and photocatalysis. However, this behavior is not observed in the case of DMDS treatment. The process requires higher cost to degrade DMDS compared to BUTY. In the case of low applied energy $\left(2.9 \mathrm{~J} \mathrm{~L}^{-1}\right)$, a loss of $15 \mathrm{~g}$. kWh${ }^{-1}$ with the combined process was observed. On the other hand, applying $9.9 \mathrm{~J} \mathrm{~L}^{-1}$, the combined process showed a gain of $4 \mathrm{~g} . \mathrm{Kwh}^{-1}$ as seen in Figure 11.

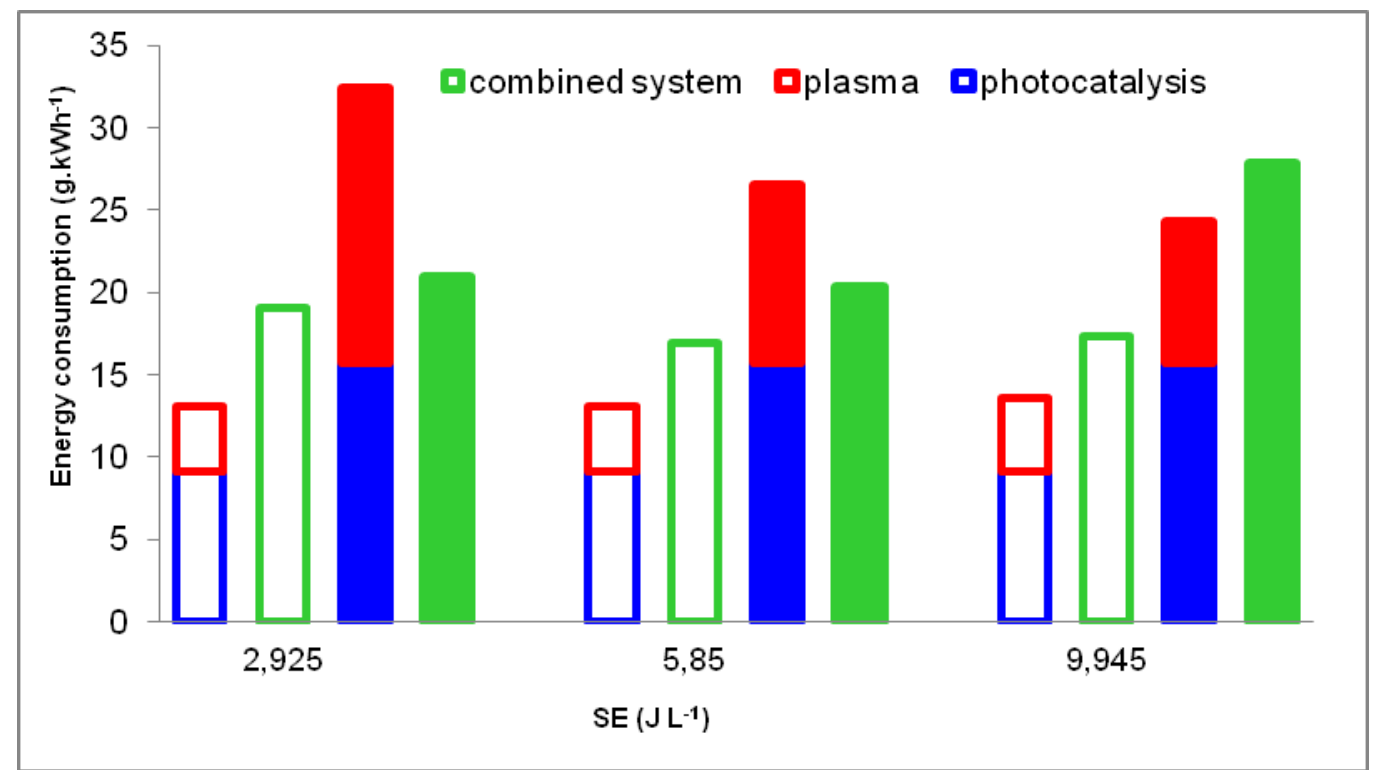

Figure 11. Variation of Energy Consumption $(E C)$ vs $S E$ at different configurations of tested processes $\left(\mathrm{Q}=4 \mathrm{~m}^{3} \mathrm{~h}^{-1}\right.$, [Pollutant] $\left.=45 \mathrm{ppm}\right)$ (dark color: butyraldehyde; light color: DMDS)

\section{Conclusion}

In this work, the degradation of butyraldehyde and dimethyl disulfide with combined plasma and photocatalysis and the influence of inlet concentration, total flow rate and SE were studied. We can note firstly, that a synergetic effect was observed of butyraldehyde removal but not in the case of dimethyl disulfide removal. This trend is due to the poisoning catalysts. Secondly, the results show that during the mixture treatment a synergetic effect was observed for the two pollutants. On the other hand, photocatalyst deactivation was observed and the regeneration could be performed by combining photocatalysis and plasma (DBD). The combined system can regenerate rapidly the catalysts; this trend can explain the synergetic effect between plasma and photocatalysis. Redox catalysis was seen to happen during the pollutants degradation concomitant with a photo-switchable hydrophilicity as detected by contact angle measurement. Moreover, Surface atomic percentage determined by XPS 
showed that the regenerated catalytic surface accumulates S2p reaching $4.44 \%$ of the total surface species which confirm the regeneration effect of plasma. Mechanism of the VOCs degradation/removal was suggested involving different oxidative processes. The energy consumption of the used processes was also estimated and discussed.

\section{References}

[1] K. Inoue, H. Okano, Y. Yamagata, K. Muraoka, Y. Teraoka, Performance tests of newly developed adsorption/plasma combined system for decomposition of volatile organic compounds under continuous flow condition, J. Environ. Sci. (2011)139-144

[2] M. Magureanu, M. Magureanu, D. Dobrin, N.B. Mandache, B. Cojocaru, V.I.Parvulescu, Toluene oxidation by non-thermal plasma combined with palladium catalysts, Front. Chem. (2013) 1-7

[3] Y. Guo, X. Liao, J. He, W. Ou, D. Ye, Effect of manganese oxide catalyst on the dielectric barrier discharge decomposition of toluene, Catal. Today (2010) 176-183

[4] T. Nevanperä, S. Ojala, N. Bion, F. Epron, R. Keiski, Catalytic oxidation of dimethyl disulfide $\left(\mathrm{CH}_{3} \mathrm{SSCH}_{3}\right)$ over monometallic $\mathrm{Au}, \mathrm{Pt}$ and $\mathrm{Cu}$ catalysts supported on $\mathrm{y}-\mathrm{Al}_{2} \mathrm{O}_{3}, \mathrm{CeO}_{2}$ and $\mathrm{CeO}_{2}-\mathrm{Al}_{2} \mathrm{O}_{3}$, Appl. Catal. B Environ. (2016) 611-625

[5] B. Darifa, S. Ojala, L. Pirault-Roy, M. Bensitel, R. Brahmi, R. Keiskia, Study on the catalytic oxidation of DMDS over Pt-Cu catalysts supported on $\mathrm{Al}_{2} \mathrm{O}_{3}, \mathrm{AlSi}_{20}$ and $\mathrm{SiO}_{2}$, Appl. Catal. B Environ. (2016) 24-33

[6] C. Guillard, D. Baldassare, C. Duchamp, M.N. Ghazzal, S. Daniele, Photocatalytic degradation and mineralization of a malodorous compound (dimethyl disulfide) using a continuous flow reactor, Catal. Today (2007) 160-167

[7] Y.H. Lin, T.K. Tseng, H. Chu, Photo-catalytic degradation of dimethyl disulfide on S and metal-ions co-doped $\mathrm{TiO}_{2}$ under visible-light irradiation, Appl. Catal. A General (2014) 221- 228

[8] S. Zhao, H. Yi, X. Tang, F. Gao, B. Zhang, Z. Wang, Ya. Zuo, Methyl mercaptan removal from gas streams using metal-modified activated carbon, J. Cleaner Production (2015) 856-861

[9] P. Doggali, Y. Teraoka, P. Mungse, I. Shah, S. Rayalu, N. Labhsetwar, Combustion of volatile organic compounds over $\mathrm{Cu}-\mathrm{Mn}$ based mixed oxide type catalysts supported on mesoporous $\mathrm{Al}_{2} \mathrm{O}_{3}$, $\mathrm{TiO}_{2}$ and $\mathrm{ZrO}_{2}$, J. Molecular Catal. A (2012) 23-30

[10] Z.S. Wei, H.Q. Li, J.C. He, Q.H. Ye, Q.R. Huang, Y.W. Luo, Removal of dimethyl sulfide by the combination of non-thermal plasma and biological process, Bioresource Technol. (2013) 451-456 
[11] N. Brodu, and H. Zaitan, M.H. Manero, J.S. Pic, Removal of volatile organic compounds by heterogeneous ozonation on microporous synthetic alumina silicate, Water Sci. Technol. (2012) 20202026

[12] K. Demeestere, J. Dewulf, H. Van Langenhove, Heterogeneous photocatalysis as an advanced oxidation process for the abatement of chlorinated, monocyclic aromatic and sulfurous volatile organic compounds in air: state of the art, Critical Reviews Environ. Sci. Technol. (2007) 489-538

[13] J. Mo, Y. Zhang, Q. Xu, J.J. Lamson, R. Zhao, Photocatalytic purification of volatile organic compounds in indoor air: A literature review, Atmos. Environ. (2009) 2229-2246

[14] M. Sleiman, P. Conchon, C. Ferronato, J.M Chovelon, Photocatalytic oxidation of toluene at indoor air levels (ppbv): Towards a better assessment of conversion, reaction intermediates and mineralization, Appl. Catal. B Environ. (2009) 159-165

[15] J. Schneider,M. Matsuoka, M. Takeuchi, J. Zhang, Y. Horiuchi, M. Anpo, D.W. Bahnemann, Understanding $\mathrm{TiO}_{2}$ Photocatalysis: Mechanisms and Materials, Chem. Rev. (2014) 9919-9986

[16] A. Bouzaza, C. Vallet, A. Laplanche, Photocatalytic degradation of some VOCs in the gas phase using an annular flow reactor: determination of the contribution of mass transfer and chemical reaction steps in the photodegradation process, J. Photochem. Photobiol. A Chem. (2006) 212-217

[17] A.A. Assadi, J. Palau, A. Bouzaza, D. Wolbert, A continuous air reactor for photocatalytic degradation of 3-methylbutanal: effect of different operating parameters and chemical degradation pathway, Chem. Eng. Res. Des. (2013) 1307-1316

[18] L.C. Chuang, C.H Luo, Characterization of supported $\mathrm{TiO}_{2}$-based catalysts green-prepared and employed for photodegradation of malodorous DMDS, Mater. Res. Bull. (2013) 238-244

[19] Y.H. Lin, H.T. Hsueh, C.W. Chang, H. Chu, The visible light-driven photodegradation of dimethyl sulfide on S-doped $\mathrm{TiO}_{2}$ : characterization, kinetics, and reaction pathways, Appl. Catal. B Environ. (2016) $1-10$

[20] A. Kachina, S. Preis, J. Kallas, Catalytic $\mathrm{TiO}_{2}$ oxidation of ethanethiol for environmentally begin air pollution control of sulphur compounds, Environ. Chem. Lett. (2006) 107-110

[21] A. Alonso-Tellez, D. Robert, N. Keller, V. Keller, A parametric study of the UV-A photocatalytic oxidation of $\mathrm{H}_{2} \mathrm{~S}$ over $\mathrm{TiO}_{2}$, Appl. Catal. B Environ. (2012) 209-218

[22] C.A. Korologos, M.D. Nikolaki, C.N. Zerva, C.J. Philippopoulos, S.G. Poulopoulos, Photocatalytic oxidation of benzene, toluene, ethylbenzene and $\mathrm{m}$-xylene in the gas-phase over $\mathrm{TiO}_{2}$-based catalysts, J. Photochem. Photobiol. A Chem. (2012) 24-31

[23] A.A. Assadi, A. Bouzaza, D. Wolbert, Photocatalytic oxidation of trimethylamine and isovaleraldehyde in an annular reactor: Influence of the mass transfer and the relative humidity, J. Photochem. Photobiol. A Chem. (2012) 61- 69

[24] C. Barakata, P. Gravejatb, O. Guaitellaa, F. Thevenetb, A. Rousseaua, Oxidation of isopropanol and acetone adsorbed on $\mathrm{TiO}_{2}$ under plasma generated ozone flow: Gas phase and adsorbed species monitoring, Appl. Catal. B Environ. (2014) 302- 313

[25] A.M. Vandenbroucke, R. Morent, N.D. Geyter, C. Leys, Non-thermal plasmas for non-catalytic and catalytic VOC abatement, Review, J. Hazard. Mater. (2011) 30- 54 
[26] H.H. Kim, Non thermal plasma processing for air-pollution control: a historical review, current issues, and future prospects, Plasma Process. Polym. (2004) 91-110

[27] C. Subrahmanyam, Catalytic non-thermal plasma reactor for total oxidation of volatile organic compounds, Indian J. Chem. Section A Inorganic Bio-Inorganic Phys. Theoretical \& Analytical Chem. (2009) 1062-1068

[28] J.V. Durme, J. Dewulf, W. Sysmans, C. Leys, H. Van Langenhove, Efficient toluene abatement in indoor air by a plasma catalytic hybrid system, Appl. Catal. B Environ. (2007) 161-169

[29] Y.S. Mok, D.H. Kim, Treatment of toluene by using adsorption and non-thermal plasma oxidation process, Curr. Appl. Phys. (2011) 1-5

[30] J. Karuppiah, E. Linga Reddy, P. Manoj Kumar Reddy, B. Ramaraju, Ch. Subrahmanyam, Catalytic nonthermal plasma reactor for the abatement of low concentrations of benzene, International J. Environ. Sci. Technol.(2014) 311-318

[31] A.A. Assadi, A. Bouzaza, M. Lemasle, D. Wolbert, Removal of trimethylamine and isovaleric acid from gas streams in a continuous flow surface discharge plasma reactor, Chem. Eng. Res. Des. (2015) $640-651$

[32] W.J. Liang, H.P. Fang, J. Li, F. Zheng, J.X. Li, Y.Q. Jin, Performance of non-thermal DBD plasma reactor during the removal of hydrogen sulfide, J.Electrostat. (2011) 206-213

[33] H.B. Ma, P. Chen, M.L. Zhang, X.Y. Lin, R. Ruan, Study of $\mathrm{SO}_{2}$ removal using non-thermal plasma induced by dielectric barrier discharge (DBD), Plasma Chem. Plasma Process. (2002) 239-254

[34] H.B. Huang, D.Q. Ye, M.L. Fu, F.D. Feng, Contribution of UV light to the decomposition of toluene in dielectric barrier discharge plasma/photocatalysis system, Plasma Chem. Plasma Process. (2007) $577-588$

[35] A.A. Assadi, A. Bouzaza, D. Wolbert, Study of synergetic effect by surface discharge plasma/TiO combination for indoor air treatment: Sequential and continuous configurations at pilot scale, J. Photochem. Photobiol. A Chem. (2015) 148-154

[36] A. Maciuca, C. Batiot-Dupeyrat, J.M. Tatibouët, Synergetic effect by coupling photocatalysis with plasma for low VOCs concentration removal from air, Appl. Catal. B Environ. (2012) 432-438

[37] J. Karuppiah, E. Linga Reddy, L. Sivachandiran, R. Karvembu, C. Subrahmanyam, Non thermal Plasma assisted photocatalytic oxidation of dilute benzene, J. Chem. Sci. (2012) 841-845

[38] F. Thevenet, O. Guaitella, E. Puzenat, J.M. Herrmann, A. Rousseau, C. Guillard, Oxidation of acetylene by photocatalysis coupled with dielectric barrier discharge, Catal. Today (2007) 186-194

[39] J. Palau, A.A. Assadi, J.M. Penya-roja, A. Bouzaza, D. Wolbert, V. Martínez-Soria, Isovaleraldehyde degradation using UV photocatalytic and dielectric barrier discharge reactors, and their combinations, J. Photochem. Photobiol. A Chem. (2015) 110-117

[40] M. Guillerm, AA. Assadi, A. Bouzaza, D, Wolbert,Removal of gas-phase ammonia and hydrogen sulfide using photocatalysis, nonthermal plasma, and combined plasma and photocatalysis at pilot scale, Environ. Sci. Pollut. Res. (2014) 13127-13137

[41] A.A. Assadi, A. Bouzaza, M. Lemasle, D. Wolbert, Removal of trimethylamine and isovaleric acid from gas streams in a continuous flow surface discharge plasma reactor, Chem. Eng. Res. Des. (2014) $1-12$ 
[42] K. Ishibashi, A. Fujishima, T. Watanabe, K. Hashimoto, Detection of the Active Oxidative Species in $\mathrm{TiO}_{2}$ Photocatalysis by Using the Fluorescence Technique, Electrochem. Comm. 2 (2000) 207-210. [43] A.A. Assadi, J. Palau, A. Bouzaza, J. Penya-Roja, V. Martinez-Soriac, D. Wolbert, Abatement of 3methylbutanal and trimethylamine with combined plasma and photocatalysis in a continuous planar reactor, J. Photochem. Photobiol. A Chem. (2014) 1-8.

[44] A.A. Assadi, A. Bouzaza, C. Vallet, D. Wolbert, Use of DBD plasma, photocatalysis and combined DBD plasma/ photocatalysis in a continuous annular reactor for isovaleraldehyde elimination Synergetic effect and byproducts identification, Chem. Eng. J. (2014) 124-132

[45] S. Gharib-AbouGhaida, A.A. Assadi, G. Costa, A. Bouzaza, D. Wolbert, Association of surface dielectric barrier discharge and photocatalysis in continuous reactor at pilot scale: Butyraldehyde oxidation, by-products identification and ozone valorization, Chem. Eng. J. (2016) 276-283

[46] J. Taranto, D. Frochot, P. Pichat, Combining cold plasma and $\mathrm{TiO}_{2}$ photocatalysis to purify gaseous effluents: a preliminary study using methanol-contaminated air, Ind. Eng. Chem. Res. (2007) 7611-7614

[47] H. Huang, D. Yea, Combination of photocatalysis downstream the non-thermal plasma reactor for oxidation of gas-phase toluene, J. Hazard. Mater. (2009) 535-541

[48] R. Portela, S. Suárez, S.B. Rasmussen, N. Arconada, Y. Castro, A. Durán, P. Ávila, J.M. Coronado, B. Sánchez, Photocatalytic-based strategies for $\mathrm{H}_{2} \mathrm{~S}$ elimination, Catal. Today (2010) 64-70

[49] H.H. Kim, S. Tsubota, M. Date', A. Ogata, S. Futamura, Catalyst regeneration and activity enhancement of $\mathrm{Au} / \mathrm{TiO}_{2}$ by atmospheric pressure nonthermal plasma, Appl. Catal. A General (2007) 93-98

[50] L. Sivachandiran, F. Thevenet, P. Gravejat, A. Rousseau, Isopropanol saturated $\mathrm{TiO}_{2}$ surface regeneration by non-thermal plasma: influence of air relative humidity, Chem. Eng. J. (2013) 17-26

[51] Y.S. Mok, E. Jwa, Y.J. Hyun, Regeneration of $\mathrm{C}_{4} \mathrm{H}_{10}$ dry reforming catalyst by nonthermal plasma, J. Energy Chem. (2013) 394-402

[52] S. Rtimi, R. Sanjines, M. Andrzejczuk, C. Pulgarin, A. Kulik, J. Kiwi, Innovative transparent nonscattering $\mathrm{TiO}_{2}$ bactericide thin films inducing increased E. coli cell wall fluidity, Surf.\& Coat. Technol. (2014) 333-343

[53] S. Rtimi, C. Pulgarin, R. Sanjines, J. Kiwi, Innovative semi-transparent nanocomposite filmspresenting photo-switchable behavior and leading to areduction of the risk of infection under sunlight, RSC Adv. (2013) 16345-16348

[54] A. Mills, S. Lee, A web-based overview of semiconductor photochemistry-based current commercial applications, J. Photochem. Photobiol. A (2002) 233-247

[55] L. Zhang, R. Dillert, D. Bahnemann, M. Vormoor, Photo-induced hydrophilicity and self-cleaning: models and realityEn. \& Environ. Sci. (2012) 7491-7507

[56] K. Seki, N. Tachiya, Kinetics of Photoinduced Hydrophilic Conversion Processes of $\mathrm{TiO}_{2}$ Surface, J. Physical Chemistry B (2004) 4806-4810

[57] S. Rtimi, Indoor light enhanced photocatalytic ultra-thin films on flexible non-heat resistant substrates reducing bacterial infection risks, Catalysts 7 (2017) 57. 
[58] S. Rtimi, S. Giannakis, M. Bensimon, C. Pulgarin, R. Sanjines, J. Kiwi, Supported $\mathrm{TiO}_{2}$ films deposited at different energies: Implications ofthe surface compactness on the catalytic kinetics, App. Catal. B Environ. (2016) 42-52.

[59] S. Rtimia, S. Giannakis, R. Sanjines, C. Pulgarin, M. Bensimon, J. Kiwi, Insight on the photocatalytic bacterial inactivation by co-sputtered $\mathrm{TiO}_{2}-\mathrm{Cu}$ in aerobic and anaerobic conditions, App. Catal. B Environ. (2016) 277-285.

[60] X. Fan, T.L. Zhu , M.Y. Wang, X.M. Li, Removal of low-concentration BTX in air using a combined plasma catalysis system, Chemosphere (2009) 1301-1306.

[61] J Y Parkdag, I Tomicicddag, G F Roundddag and J S Changdag, Simultaneous removal of NOx and $\mathrm{SO}_{2}$ from $\mathrm{NO}-\mathrm{SO}_{2}-\mathrm{CO}_{2}-\mathrm{N}_{2}-\mathrm{O}_{2}$ gas mixtures by corona radical shower systems, J. Phys. D: Appl. Phys. (1999) 1006-1011. 